\title{
Study on learning landscape outdoor space of primary school campus based on Permaculture and symbiotic theory- - Hefei Experimental School as an example
}

\author{
Zhang Shaojie ${ }^{1,2,3, *}$, Yin $\operatorname{Limin}^{1}$, Zhang Yunle ${ }^{1}$, Zheng Shuhan ${ }^{1}$, and Zhang Tong ${ }^{1}$ \\ ${ }^{1}$ Anhui Jianzhu University, Architecture and Planning. 230022 Hefei Anhui, China \\ ${ }^{2}$ BIM Engineering Center of Anhui Province. 230022 Hefei Anhui, China \\ ${ }^{3}$ Anhui Jianzhu University, Built Environment and Health Research Center. 230022 Hefei Anhui, China
}

\begin{abstract}
With the study of the relevant literatures and applications of Permaculture and symbiotic theory, this paper deeply explores its theoretical significance for the outdoor learning landscape planning and design of modern primary schools. We provide a fuller and more realistic understanding on the outdoor landscape of the campus that adapts to the growth and development of children in primary school, so as to find a practical reference for the outdoor learning landscape construction of primary school campus that plays the greatest role of natural education.
\end{abstract}

\section{Preface}

With the rapid development of education, primary education has been universal. In October 2015, the second-child policy of the Fifth Plenary Session of the 18th CPC Central Committee was opened which lead to the number of children increased significantly. But most primary schools, which were established early, had only basic landscape facility in the construction of the campus environment. Facing rapid growth in the number of children, primary and secondary education should be improved timely in terms of scale, structure and quality. The classroom is the main position of education in the traditional education system. But schools also need to provide a certain amount of time outdoor activities for students to ensure the health of children. "Education is life, life is society. " the American educator Dewey put it. Education has a close relationship with daily activities while closed spaces cannot cultivate children's social perception ability. Nowadays, "Open education" has been promoted by foreign scholars. Chen Heqin, a childhood educator in China, put forward the theory of "living education", which holds that "nature" is a real book, a living, direct book as opposed to "dead knowledge" in books.

In summary, over the years many scholars at home and abroad have elaborated on the function of natural education, which shows that the significance of the outdoor space landscape on campus, and that "natural education" is the key development direction of outdoor space construction in primary schools. The study takes Hefei Experimental School as the research object, takes the outdoor participation in the primary school's outdoor learning landscape space as the direction, and supported by the theory of Permaculture and symbiotic theory to explore the application of outdoor landscape design in natural education.

Permaculture and symbiotic theory aim to create a three-dimensional sustainable design structure that can be adapted to various environments, which focus on discovering, exploring the laws of nature and respecting for the intrinsic connections of ecological systems. In this ecosystem, a self-cycle will be formed, without excessively depending on external resources, which increases the ecological benefits of the campus landscape to achieve the effects of low-carbon, circulation and treatment. It assists in selecting campus location, choosing building materials, managing practice decision-making to serve the school classroom practice.

With multi-functional landscape planning and design, children are provided with the opportunity to participate in different activities. Based on the superposition of different functional levels, a multi-functional space for children's outdoor activities is built, providing a place for children to play and ecological education so that they can experience nature most directly.

\section{Learning landscape}

\subsection{Definition of a learning landscape}

Learning landscape, a kind of teaching goes together with pleasure, which integrates curriculum knowledge, the needs of quality education and children's health development into campus outdoor design, extends landscape of classroom teaching. Introducing learning landscape to the primary school campus can both make up the limitations of indoor teaching, fully tapping the

\footnotetext{
* Corresponding author: 48937478@qq.com
} 
wasted large outdoor space's potentialities, and can meet the need of the development of the children at this age, developing children's various abilities and the spirit of exploring knowledge, building a kind of landscape that helps teaching, which creates a campus environment construction of indoor and outdoor common learning and aims at the goals of quality education.

\subsection{Analysis on the current situation of outdoor space in primary schools of China}

With the research on the primary school campus in different levels of development cities of China, we can find that the outdoor spaces of primary schools of China have the following characteristics: different levels of campus space due to different urban development levels, outdoor space of primary school is far less than the indoor space, and the types of activities that can occur in outdoor space is single, such as the court, playground, parterre, etc., resulting in the type of activity that can occur is lacking in changes. How to introduce the learning landscape theory to the primary schools of our country should be started with the needs of primary school students.

\section{The research object}

\subsection{Definition of relevant research concepts}

(1) School-age children

School-age children refers to children who entered school aged 6-7 to those who begin adolesce aged 12-14. This paper studies the outdoor landscape of primary school campus with 7-12 years old children as the main body.

(2) Primary School Campus

Primary school campus refers to place where schoolage children take basic education and take daily activities. This paper mainly studies the general primary school campus which is suitable for most school-age children.

(3) outdoor space landscape of primary school campus

Outdoor space landscape of primary school campus refers to the infrastructures of outdoor space, which is based on the psychological and physical development needs of school-age children, and can convey the spiritual and cultural connotation with educational significance while providing basic ornamental functions.

\subsection{Design evidence - Hefei Experimental School outdoor landscape space optimization}

\subsubsection{Hefei experimental school campus overview}

\section{(1) Location}

The project is located at the intersection of Ulumuqi Road and Ningxia Road, Baohe District, Hefei city. Its north and east sides are high-rise residential areas, and the south and west sides are industrial parks of Hefei city.
It is close to metro line 5 and Hefei south railway station, which has great development potential.

(2) Current landscape situation

The south courtyard uses irregular layout of garden road, and the three corridors intersect the main garden road of entrance at the small square of tree pool in the center of the courtyard, with a width of 1.5 meters. The second-class garden road with a width of 1-meter layout some rest stone chairs along the garden road, and the garden is planted with a variety of plants. The north courtyard garden roads adopt a regular layout, with a small square in the north, a gallery in the south, and the rest of the space planted with plants. There is no sense of hierarchy in plant landscape, and the function tends to be single.

(3) Distribution of student activities

According to our statistics, the distribution density of student activities is relatively high in the plant planting area in the middle of the courtyard. In the north courtyard, the distribution density is higher in the corridor shelf area, because they play games under the corridor shelf for a long time, while in the small open square of the northern courtyard, the distribution density of is not much.

\subsubsection{Analysis of the psychological and physiological development needs of school-age children}

At the age of 7-8, school-age children have acquired the ability of direct imitation of objective things, and the logical thinking ability of abstract images is still in the process of development.9-12 years is an important period when the internal structure of brain cells is gradually improved and thinking ability is exercised (table 1). Therefore, in order to meet the needs of schoolage children in improving physical quality, cultivating behavioral cognition and social emotion, primary schools need to provide outdoor activity space with certain functions for comprehensive quality education.

Table 1. The psychological type and characteristics of schoolage children

\begin{tabular}{|c|l|}
\hline Type & \multicolumn{1}{|c|}{ Characteristics } \\
\hline $\begin{array}{c}\text { Attention and } \\
\text { will }\end{array}$ & $\begin{array}{l}\text { Involuntary attention is dominant, which is } \\
\text { unstable and easily distracted. Attention of } \\
\text { children is easily attracted by interest, } \\
\text { intuitive, and manifests emotional color. }\end{array}$ \\
\hline Cognitive \\
activity & $\begin{array}{l}\text { Perception is conscious and purposeful, but at } \\
\text { a limited level. Involuntary memory gradually } \\
\text { gets the advantage. Thinking level is at } \\
\text { transition phase from concrete image to } \\
\text { abstract logic. }\end{array}$ \\
\hline Personality & $\begin{array}{l}\text { Pupils are active, preferring to imitate, and } \\
\text { easily to be implied }\end{array}$ \\
\hline Emotion & $\begin{array}{l}\text { Emotion is increasingly abundant, while } \\
\text { morality being greatly developed, and the } \\
\text { control of emotion is enhanced. }\end{array}$ \\
\hline
\end{tabular}

3.2.3 The requirements of school-age children's behavior on the outdoor learning space landscape in campus 


\section{(1) Security}

Since the physical functions of school-age children are not fully developed, and social behavior awareness is still in the ignorant period, the construction of outdoor space in campus must take safety as the priority. It's required to avoid using facilities, plants, etc. that may adversely affect children.

(2) The diversity of space functions and forms

The outdoor space in campus needs to meet the basic functions of children's activities, intellectual exploration and cognition of nature, etc. In addition, cultural education is conveyed in different forms of expression to enlighten and inspire children's daily games and sports. (Fig.1)

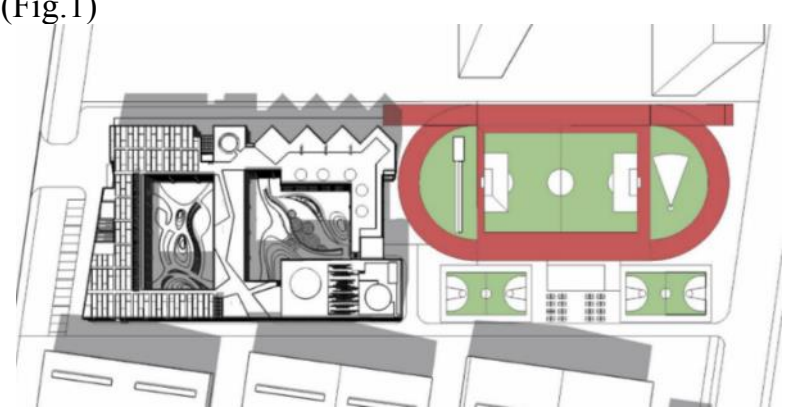

Fig.1. Hefei Experimental School Floor Plan.

(3) The scale rationality of space and facilities, etc.

The outdoor space landscape of campus construction should not only offer the space for children to observe, perceive and play in terms of sketches, game facilities and plant landscape, but also take care of the difference of the physiological development between junior students and senior students, so as to create outdoor landscape suitable for school-age children at different developmental stages.

\subsubsection{The Space Landscape Design Analysis of Outdoor Space in Hefei Experimental School}

Based on the investigations and researches on the campus of Hefei experimental schools, under the requirements of rigid norms and safety standards, the space form design of outdoor space landscape construction is greatly limited, while students mainly perform activities indoors.

(1) Activity area analysis

For the square activity space, there exists no activity facilities, insufficient shade, lacking of function division. For the courtyard space, Hefei Experimental School has two courtyard space, because of the courtyard space is the nearest outdoor space, children at recess often like performing activities in huge bands. The courtyard space design of Hefei Experimental School lacks of consideration for children's recess group activities, while garden roads are narrow, providing insufficient activity space, with only a few facilities. For the sports area, only sports and fitness equipment facilities, lacking of facilities for games and recreation (Table 2).
Table 2. Status of student activity space types.

\begin{tabular}{|l|c|c|c|}
\hline Space type & behavior Type & $\begin{array}{c}\text { Occurrence } \\
\text { Time }\end{array}$ & $\begin{array}{c}\text { Time } \\
\text { ratio }\end{array}$ \\
\hline Classroom & studies & Class time & $77 \%$ \\
\hline $\begin{array}{l}\text { South Court, } \\
\text { North Court, } \\
\text { Corridor, } \\
\text { Playground }\end{array}$ & $\begin{array}{c}\text { Amusement, } \\
\text { relaxation } \\
\text { Lecture Hall }\end{array}$ & $\begin{array}{c}\text { Recess, lunch } \\
\text { breaks }\end{array}$ & $10 \%$ \\
\hline Canteen & Meal & $\begin{array}{c}\text { School } \\
\text { organization } \\
\text { time }\end{array}$ & $2 \%$ \\
\hline
\end{tabular}

(2) Single function of outdoor space

According to the investigation and study, the outdoor space of Hefei Experimental School is mostly ornamental landscape, and the scope of children's activities is fixed in some defined activity areas, leading to the relationship with nature being cut off to some extent. In addition, the image of the ground pavement and entertainment facilities is relatively single and boring, which being difficult to touch the spiritual level of children, and unable to carry out comprehensive education from various perspectives. (Fig.2, Fig.3)

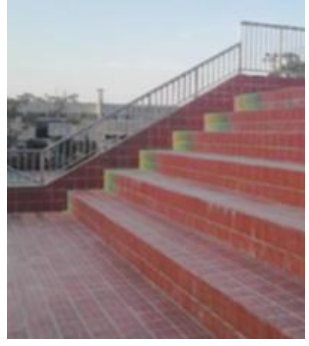

Fig.2. The current situation of Hefei Experimental School

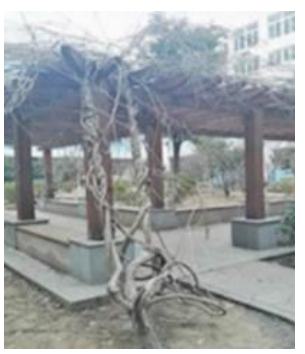

Fig.3. The current situation of Hefei Experimental School

\section{Strategies for remodeling promotion}

For the outdoor activity space of experimental primary schools and the needs of primary school students, we can adopt the following methods:

(1) Plants are used to create outdoor activity spaces for primary school students which are labeled the name, flowering period, growth habits, etc. Learning the laws of nature in the process of observing the experience and playing to meet students' outdoor landscape experience and enlightening needs. According to the scientific regulation of plant growth, size and color change, different plant theme spaces are created to ensure the inspiration and experience of the landscape space. In 
addition to creating horticultural exploration spaces to accommodate students' inspirational and experiential needs for landscapes, it is also possible to combine planting maze space with low coverage that obscures students' horizons, combining heuristics with participatoryness.

(2) Add activity and game facilities: students' needs for outdoor landscape inspiration, experience and creativity can be satisfied by adding competitive game facilities, multi-player cooperative game facilities and natural game facilities with materials. At the same time, solving problems in the game with others can not only cultivate students' ability to cooperate and cooperate, but also improve students' creativity.

(3) Courtyard space landscape: different landscape elements are used to create outdoor space that adapts to different behaviors. The courtyard space is mainly for students' activities and rest places. It is necessary to use various landscape elements to create different landscape spaces to meet the different behaviors of students, to avoid mutual interference of various behaviors and to enrich the spatial level. For instance, leisure seats can be set around the courtyard which should meet the physiological standards of students of different age groups.

(4) Sports space landscape: sports space is the place where outdoor activities take place most in primary schools. The design of sports field should take into account the needs of students with different behaviors. The edge of the standard movement facilities can be softened by trees to form a centripetal space. The nonstandard functional area around the movement field is set with viewing space for students to have a rest.

\section{Conclusion}

At present, people in China only pay attention to the enrollment rate and the education level of the school while ignored the outdoor environment of primary school campus. Most schools still put the emphasis on classroom teaching, insufficient attention was paid to the "second class". In recent years, "sustainable development" of landscape is being implemented, campus landscape construction should also learn from part of the theory to build ecological friendly and return to the nature of the civilized campus. The campus landscape construction also carries on the nature education to the school age children to cultivate the concept of ecological civilization for children, which for the formation of a correct world view, values, outlook on life lays a solid foundation.

Although we consider that the outdoor learning landscape classroom cannot completely replace the traditional classroom learning, which promotes educational model and teaching diversity in the classroom in a way, which lets the primary school campus environment full of new ideas. Most importantly, it reduces the sense of alienation and strangeness between children and nature, which is better for their physical and mental development.

\section{Acknowledgement}

The authors appreciate the financial support from 2019 Anhui Province Housing Urban and Rural Construction Science and Technology Program Project(2019-rk001) and Provincial Teaching Research Project of Anhui Jianzhu University(2017jyxm0349), 2019 Provincial University Innovation and Entrepreneurship Training Program Project of Anhui Jianzhu University(S201910878149), 2019 National University Innovation and Entrepreneurship Training Program Project of Anhui Jianzhu University (201910878081), 2019 National University Innovation and Entrepreneurship Training Program Project of Anhui Jianzhu University (201910878109).

\section{References}

1. Jie L, Fensheng L. Analysis on Thoughts of the Sustainable Development in Permaculture [A]. Journal of China University of Petroleum (Edition of Social Sciences) (2017)

2. Jia H. Research on Planning Strategy for the Sustainable Campus Based on the Symbiosis Concept [D]. South China University of Technology Guangzhou (2011)

3. MaoZheng F. A Design Research on Involving Learning Landscape into the Outdoor Space of Primary School Campus [D]. China University of Mining and Technology (2014)

4. Jiayin Y. The Study of primary school's public space design based on the need of children's psychological development [D]. Zhejiang University (2018)

5. Fan Y. Study on outdoor learning landscape design of primary school Fuzhou Jinshan primary school as an example [D]. Fujian Agriculture and Forestry University (2017)

6. Yao Z. Study on the optimization strategy of outdoor space landscape in primary school based on student behavior [D]. Anhui Jianzhu University (2018)

7. Richard P Dobel, Translation of Beijing Century English Translation Co. Ltd. Campus ViewFunction Form Real case[M]. China Water\&Power Press, Intellectual Property Publishing House (2005)

8. [Denmark]Jan G, He Renke Translated. Livet mellem husene, udeaktiviteter og udemiljøer [M]. China Architecture \& Building Press (2002)

9. Cooper A R, Page A S, Wheeler B W, etal. Patterns of GPS Measured Time Outdoors after School and Objective Physical Activity in English Children:

the PEACH Project[J]. International Journal of Behavioral Nutrition \& Physical Activity (2010)

10. O zdemir A, Yilmaz O. Assessment of Outdoor School Environments and Physical Activity in Activity in Ankara's Primary Schools[J]. Journal of Environmental Psychology, (2008)

11. Fjortoft I. Landscape as Playscape: The Effects of Natural Environments on Children' s Play and 
Motor Development[J]. Children Youth \& Enviroments (2004)

12. Lieberman GA, Hoddy L L.Closing the
Achievement Gap: Using the environment as an intergrating context for learning $[\mathrm{J}]$.Academic Achievement (1998) 